\title{
【研究ノート】
}

\section{タンザニア産コーヒー豆の輸出構造と価格形成制度 一日本への輸出を事例としてー}

\section{金沢大学経済学部 辻村 英之}

1. 本論の問題意識と分析課題

2 . 輸出量・輸出価格と日本の位置

1 ) 輸出量と輸出価格の変化

2 ) 主要輸出相手国と日本の位置

3. 日本への輸出の経路と形態

1）日本への国際流通経路

2 ）日本の大手総合商社による購入形態 ーニチメン経路を中心にー

4. 支配的輸出経路における価格形成制度

1) 輸出価格・競売価格·先物価格の関係

2 ) 輸出価格形成の仕組み

3 ) 割増・割引額の程度

5 . 輸出価格形成制度の本質的問題と対応方 向一生産者価格引き上げ方策の探求のた めに-

\section{1 . 本論の問題意識と分析課題}

タンザニアで生産されるコーヒー豆の 97.8 \%（1998年度・註 1）は、輸出に向けられて いる。ところが同国において、コーヒー輸出 を主要な分析対象とする研究に関しては、国 際商品協定 (輸出割当制度) がコーヒー産業 や国民経済に与える影響を分析する、70年代 後半の論文に限られてしまう（Mahalu [2]， Musuya[3])。本論は、その先行研究に乏し いタンザニア産コーヒー豆輸出の実態を、で きる限り具体的に解明しょうとするものであ る。分析事例として取り上げるのは、最も重 要な輸出相手国の 1 つである日本への輸出構 造である。

さて分析対象をコーヒー産業全体に拡大し てみても、それがタンザニア最大の輸出産業
であるのにもかかわらず、先行研究はあまり 多くない。流通自由化（94 年）以後の研究 で、本論の問題意識に触れる重要な論文は、 以下の 2 つである。

チェンザは、経済自由化がコーヒー生産者 の所得に与えた影響を計量分析する。その結 果、コーヒー生産者の実質所得が降下したこ とを明らかにしている。その原因としては、

1) 投入財に対する補助金廃止と通貨切り下 げが、投入財（主に輸入品）の価格を高騰さ せたこと、その一方で、2 ) 国際価格の低迷 がゆえに、生産者価格が十分に上がらないこ と、を挙げている。そして国際価格低迷の原 因として、北アメリカやヨーロッパの伝統的 消費国の嗜好が、コーヒーから清涼飲料に変 化したという、需要量の低迷を挙げている (Chenza [4])。

彼の議論に誤りはないが、重要な問いに欠 けている。タンザニア産のマイルド・アラビ カ種コーヒー豆（日本では「キリマンジャ ロ・コーヒー」と呼称）は、最高品質豆とし て差別化されている。そうであるのにもかか わらず、どうして国際価格（ニューヨークの コーヒー・砂糖・ココア取引所で決まるアラ ビカ種コーヒー豆の平均先物価格）の低迷 が、そのままタンザニア産豆の輸出価格や生 産者価格の低迷に結び付くのかという問いで ある。例えば、「キリマンジャロ・コーヒー」 を特別に嗜好する消費者が多ければ、世界の コーヒー豆の需要量低迷が、タンザニア産豆 の需要量・価格低迷につながらない可能性も あるはずである。

新制度学派や産業組織論の分析枠組を援用 
して、自由化後のコーヒー市場の変化を実証 分析するテムは、1)流通コストの削減、2) 生産者価格の上昇、3) 物的 - 人的資本の改 善、を理由として、逆に自由化の成功を強調 している。またタンザニアのモシ市にあるコ 一ヒー競売所に関しても、競売価格の国際価 格への連動がゆえに、「価格発見」と「農民に 対する価格情報源」の役割を発揮している と、高く評価している (Temu [5])。

彼女の議論に対しても、チェンザの場合と 同様、国際価格や輸出価格に対する理解不足 を指摘できる。ニューヨーク先物価格への連 動がゆえに、モシ競売所は確かに「コーヒー 豆の国際価格」の情報源として機能してい る。しかしそれは、「タンザニア産豆の独自の 価格」を発見しているわけではない。逆に価 格発見機能を発揮できていない欠点として、 評価されなければならないと考える。

どちらの議論も価格形成制度、特にタンザ ニア産豆の輸出価格がいかに設定されるの か、そしてその輸出価格とニューヨーク先物 価格、モシ競売価格、生産者価格の間の関係 について、具体的な分析に欠けているという 弱点がある。それゆえ、特に流通構造の本質 的問題の解明や、それを解決するための具体 的方策の提起につながらないのである。

既に著者は拙稿において、ニューヨーク先 物価格とモシ競売価格、生産者価格の間の相 関関係とその理由を解明した。さらには、流 通自由化によりコーヒー豆の買付競争を促 し、生産者価格を引き上げる構造調整政策の 手法が、ほとんど機能していないことを明ら かにした。その要因の 1 つとして、輸出価格 の設定方法を挙げることができるのである (拙稿 $[6]$ )。それゆえ、後は輸出価格形成の 仕組みが明らかになれば、生産者価格を引き 上げ、小農民の貧困を緩和するための新たな 方策が浮かび上がってくると考える(註 2$) 。$ そこで本論では、先行研究に欠ける、1) タンザニア産コーヒー豆の日本への輸出構造
の現状分析、を試みるが、その主要な目的 は、2）輸出価格形成制度の詳細なる解明、 3 ) 同制度の本質的な問題点の解明、であ る。それは上記の理由で、生産者価格引き上 げの方策を探求するための、基本的要件の提 示に等しいのである。以上の 3 つが、本論の 分析課題である。

なお本論は、主に高品質レギュラー・コー ヒーとして消費される、マイルド・アラビカ 種のコーヒー豆を中心に分析する。さらに利 用するデー夕は、1998年 $1-2$ 月、1998年 8 -9 月、1999年 $8-9$ 月、 2000 年 8 月の現地 調查(資料収集と聞き取り調查)、および国内 における資料収集と聞き取り調査（99 年 6 月、10月、12月) で収集したものが中心とな る(註 3$)$ 。また複数のインフォーマントから 聞き取ったデータに関しては、出所先は明記 しない。また本文中の「年度」はコーヒー年 度 (10月-9月) を指す。

\section{2 .輸出量・輸出価格と日本の位置}

\section{1 ) 輸出量と輸出価格の変化}

1981 年度に 53,164 トンの輸出数量 (Mwaikambo [7] Appendix 5) を実現した 以降、タンザニアにおけるマイルド・アラビ カ豆の輸出数量は減少し、表 1 で確認できる ように、近年は停滞したままである。輸出価 格 (FOB) と輸出総額に関して、最高は 85 年 度の 187.50 USドル $/ 50 \mathrm{~kg} 、 138.0$ 百万USドル であり(Ibid.)、特に近年の輸出総額はその最 高值を大きく下回っている（表 1 )。

その一方で、81年度に3,337トンであった日 本へのコーヒー(アラビカ豆、ロブスタ豆、イ ンスタント)の輸出数量 (Daily News [8])、 そして 10.1 百万USドルであった輸出総額は （註 4 ）、10年を経た近年、共に2.0-3.5倍に 大きく増加している（輸出価格はあまり変化 していない・註 5 )。

日本へ輸出するコーヒーのほとんどがマイ 
タンザニア産コーヒー豆の輸出構造と価格形成制度

表 1 輸出の数量と価格（マイルド・アラビカ豆）

\begin{tabular}{|l|l|l|l|}
\hline 年度 & 数量(トン) & 価格 (US\$/50kg・FOB) & 総額（百万 US\$） \\
\hline $1992 / 93$ & $43,704(12,424 / 28.4 \%)$ & $69.23(85.44)$ & $60.5(21.2 / 35.0 \%)$ \\
\hline $1993 / 94$ & $25,675($ n. a. $)$ & $100.24 （$ n. a. $)$ & $51.5($ n. a.) \\
\hline $1994 / 95$ & $26,341(8,372 / 31.8 \%)$ & $177.97(192.22)$ & $93.8(32.2 / 34.3 \%)$ \\
\hline $1995 / 96$ & $42,872(10,851 / 25.3 \%)$ & $116.66(125.34)$ & $100.0(27.2 / 27.2 \%)$ \\
\hline $1996 / 97$ & $28,413(7,264 / 25.6 \%)$ & $129.02(148.92)$ & $73.3(21.6 / 29.5 \%)$ \\
\hline $1997 / 98$ & $24,073(6,847 / 28.4 \%)$ & $171.69(211.21)$ & $82.6(28.9 / 35.0 \%)$ \\
\hline $1998 / 99$ & $26,009(8,845 / 34.0 \%)$ & $129.89(166.63)$ & $67.6(29.5 / 43.6 \%)$ \\
\hline
\end{tabular}

註：1）（）内は日本への輸出、及び同輸出の全体に占める割合。

2 ) Tanzania Coffee Board, Cummulative Coffee Exports, を参照して作成。

ルド・アラビカ豆である（96年度 100\%、97 年度 $96.5 \% 、 98$ 年度 $99.5 \%)$ 。それゆえ、上記 の 10 年間における輸出量 - 額の大幅な増加 は、マイルド・アラビカ豆に限っても当ては まる(表 1 )。

\section{2 ) 主要輸出相手国と日本の位置}

マイルド・アラビカ豆の輸出数量が停滞し ているのにもかかわらず、日本への輸出数量 が大幅に増加しているならば、当然、輸出量・ 額に占める日本の割合の大幅な上昇を予測で きる。

81 年度においては、日本への輸出数量は全 輸出数量（アラビカ豆、ロブスタ豆、インス タント）の $5.8 \%$ を占めるに過ぎなかった。 同年度の最大の輸出国は西ドイツ $(46.6 \%)$ で、以下、イタリア $(11.5 \%)$ 、東ドイッ $(8.8$

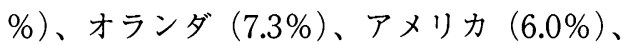
日本（6 位）の順であった（註 6 )。

ところが 10 年を経た近年、全輸出数量 (ア ラビカ豆、ロブスタ豆、インスタント）に占 める日本への輸出数量の割合は $18-22 \%$ (註 7 )、マイルド・アラビカ豆に限ると $25.3-$ 34.0\%に至っている (表 1 )。同様に輸出総額 も、前者が $22-31 \%$ 、後者が $27.2-43.6 \%$ で ある。この 7 年間は輸出の数量も総額も、と
もに第 2 位の位置を占めている（98年度に、 マイルド・アラビカ豆の輸出総額が初めて 1 位となった)。

なお第1位はともにドイッであり、マイル ド・アラビカ豆の数量が $45-55 \%$ 、総額が 40 -50\%を占める。以下、オランダ、ベルギー、 フィンランド、アメリカが続いているもの の、日本とドイッで輸出量・額の約 4 分の 3 を占めていることになる（図 1)。

さらにドイッへの輸出は、ブレンド用に利 用されることが多いため、安価な南部産豆が 中心である一方で、ストレート用に利用され ることの多い日本への輸出は、高価な北部産 豆が中心である。その結果、上記の主要輸出 国（6 力国）に限って輸出価格（92 年度以 降）を比較した場合、日本は常に $1-2$ 位に 位置するのに対し、ドイッは $3-6$ 位にい る。最も高価な北部産マイルド・アラビカ種 の高品質豆は、そのほとんどが日本に輸出さ れていると言ってもよい。

\section{3 . 日本への輸出の経路と形態}

1）日本への国際流通経路

上記のように、約 3 割のマイルド・アラビ カ豆、とりわけほとんどの最高価豆が日本向 
図 1 主要輸出国への輸出数量の割合 (マイルド・アラビカ豆)

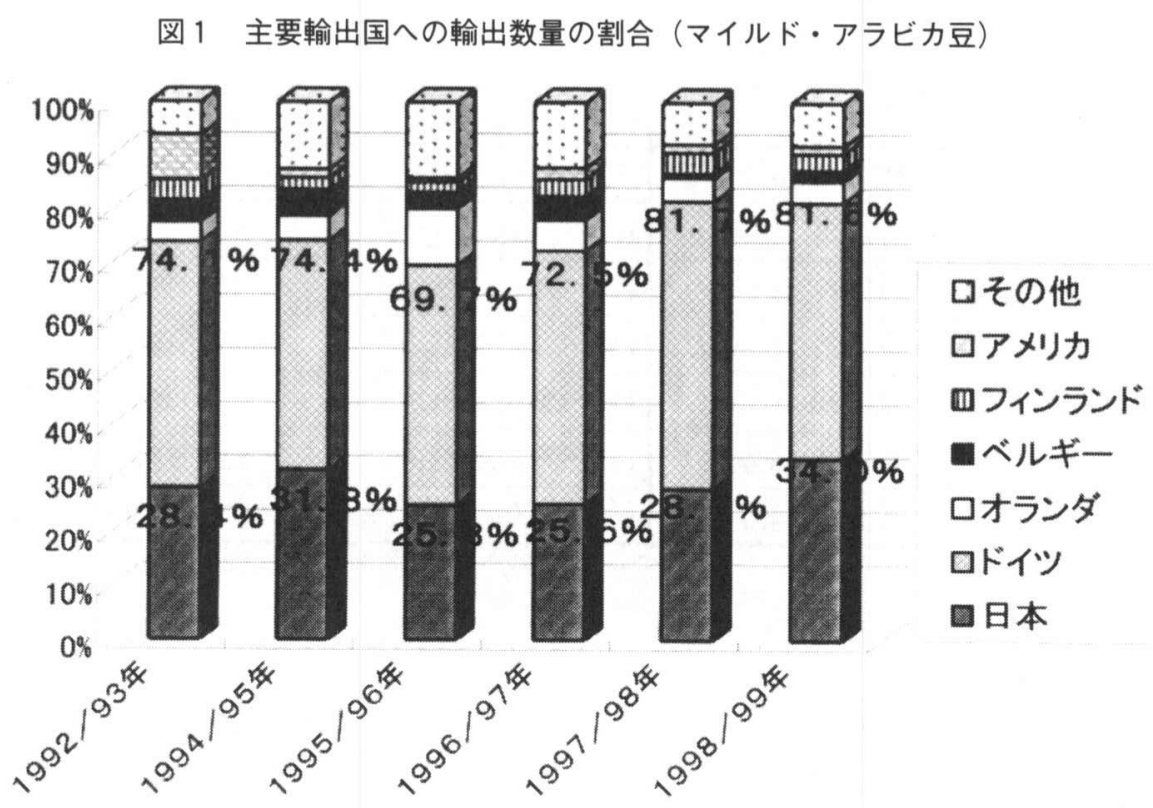

註：Tanzania Coffee Board, Cummulative Coffee Exports, を参照して作成。

けであるのにもかかわらず、さらには自由化 にともない、輸出免許（競売への参加資格） の取得が容易になったのにもかかわらず (97 年11月には、20社の輸出業者がコーヒー豆を 輸出)、モシで行われる競売に、日本の業者は 参加していない。競売所でコーヒー豆を購入 するためには、拙稿で説いた民間業者による 共謀等、特殊な専門性が求められる(註 8 )。 それが日本の業者による新規参入の障壁にな っている。それゆえ日本の業者は、競売に長 年参加している輸出業者 (シッパー) から、 生豆を購入している。

コーヒー流通公社における聞き取り調査で 確認できた、 2 力月間 (97年 9-10月) の日 本の業者によるマイルド・アラビカ豆の購入 は、1）大手総合商社によるもの（アフリカ コーヒー会社 $(\mathrm{ACC} ・$ ・ギリス系) $\rightarrow$ ニチメ ン、テイラー・ウィンチ (スイス系) $\rightarrow$ 三菱 商事、コーヒー・エクスポーターズ (インド 系） $\rightarrow$ 三菱商事、オラム (インド系) $\rightarrow$ 伊藤 忠商事、ドルマン (イギリス系) $\rightarrow$ 伊藤忠商
事)、2 ) コーヒー焙煎・製造業者 (ロース夕 一) によるもの（テイラー・ウィンチーネス レ日本)、 3 ) 専門商社によるもの(テイラー。 ウィンチ $\rightarrow$ ウルカフェ(コーヒー専門商社)、 ドルマン $\rightarrow$ 加商（穀物専門商社））、の 3 つに 分類することができる。

倉庫 (北部産豆は主にモシ、南部産豆は主 にマカンバコかムボジ）から港（北部産豆は タンガ、南部産豆はダルエスサラーム) への 輸送は、輸出業者がトラック（約 7 割）また は列車 (約 3 割) を利用して行う(運送業者 に委託)。さらに日本への海上輸送は、日本郵 船か商船三井を利用する。一般的には、それ らに船積みした時点で、豆の所有権が日本の 業者に移る。

2 ）日本の大手総合商社による購入形態 ーニチメン経路を中心にー

上記の 3 つの購入経路（多国籍輸出業者 $\rightarrow$ 日本の輸入業者) の内、1) の大手総合商社 による購入が、タンザニア産コーヒー豆の日 
本への支配的輸出経路である。ただニチメ ン、三菱商事、伊藤忠商事の 3 社ともに、モ シに事務所を有しておらず、ニチメンと伊藤 忠はケニア・ナイロビ事務所、三菱はロンド ンの英国三菱（ナイロビ事務所に購入を指 示）が、同豆の購入を担当している。

三菱と伊藤忠は、複数の輸出業者からの購 入であるのに対し、ニチメンはACCと固定 的、排他的な関係を結んでいる。つまりニチ メンはACCからのみ、タンザニア産豆を購入 しており、またACCも基本的にはニチメンの みに、日本向けの同豆を販売している（註 $9)$ 。以下、このニチメン経路の詳細を明示す る。

ACC（註 10）が輸出するタンザニア産マイ ルド・アラビカ豆は、97年度で約 4 千トンで あるが、その内の $5-6$ 割をニチメンが購入 していると言う(註11)。それゆえ概算ではあ るが、日本へ輸出される同豆の $29-35 \%$ が、 ニチメン経路を流れていることになる。

まずニチメン日本本社からの引合（階級お よび総合品質、船積時期、数量、価格等の指 示)を得て、ニチメン・ナイロビ事務所は $\mathrm{ACC}$ ナイロビ支社との交渉に入る。ACCナイロビ 支社はモシ支社からの情報、またニチメン . ナイロビ事務所は日本本社からの情報を踏ま え、交渉を進める。契約が成立した場合、ACC ナイロビ支社は当該豆の購入あるいは輸送 を、モシ支社に指示するのである。

また近年、タンザニア産コーヒー豆は品質 の均一性に欠けるため、船積前サンプル承認 条件（註 12）での契約が望ましい。ニチメン はナイロビ事務所にコーヒー専門家を駐在さ せているため、この船積前サンプルの品質検 査が充実していると言う。

ACCがニチメンから注文を受けるコーヒー 豆の階級および総合品質は、AA FAQ（大き さ、形、重さ、色ともに最高級豆であるAA階 級の標準的な（Fair Average Quality）総合品 質 (香味を含む)) 以上がほとんどである。ま
た $\mathrm{A}$ と $\mathrm{B}$ の混合である $\mathrm{AB} \mathrm{FAQ}$ 以上の注文も ある。

AA FAQ以上の階級および総合品質という のは、拙稿で説いたコーヒー流通公社 (TCB) 管理の格付制度によれば、上質なもの から順にAA Fine、AA Good、AA Fair to Good、AA FAQ Plus、AA FAQの 5 種類を指 す（註13）。しかし各輸出業者は、同規格とは 別に独自の規格をそなえており、それは一種 のブランドとして機能している。例えばACC は、AA FAQを超える上質豆として、上から 順にAA Kibo (キボ)、AA Kilimanjaro(キリ マンジャロ）という規格を持つ。同様に $\mathrm{AB}$ 階級に関しても、AB FAQを超える上質豆と して、AB Mawenji (マウェンジ) という規格 を持つ。

近年、それらの最高品質豆はほとんど出荷 されないため、価格は大きく跳ね上がる。そ の高価さにもかかわらず、FAQを超える最高 品質豆を求めるのは、タンザニア産マイル ド・アラビカ豆をブレンドせずに、ストレー トで消費することの多い日本のみである。そ れゆえ上記のブランドは、ほとんど日本への 輸出（ニチメンへの販売）のみに利用される 格付であると言う。

なおタンザニアの輸出業者と日本の大手総 合商社による価格設定の仕組みに関しては、 次節で詳細に分析する。

\section{4. 支配的輸出経路における価格形成 制度}

1 ) 輸出価格·競売価格 · 先物価格の関係 拙稿で解明したように、民間・支配的流通 経路において、モシ競売所での取引はほとん ど意味を持たない。競売される豆の販売者 (買付・加工業者) と購入者 (輸出業者) が同 じであり、取引（競売）価格がどんな水準で あっても、企業内の取引に過ぎないからであ る。またこの所有権不移動取引が円滑に進む 
ように、民間業者は他社所有豆の競売には口 を出さないという共謀を行っている（註 14)。

日本への大手総合商社 - 支配的輸出経路 は、この支配的国内流通経路とつながってい る。上記のように競売所で購入競争がなされ ていないため、輸出価格（FOB）が競売価格 を下回る逆ざや現象が生じることが少なくな い。例えば 98 年 2 月 26 日の北部産アラビカ豆 の平均競売価格が4.86USドルであるのに対し (Tanzania Coffee Board [12])、3 月の日本 への平均輸出価格は $4.38 \mathrm{US}$ ドル $/ \mathrm{kg}$ である (Tanzania Coffee Board [13])。

ただし競売価格も輸出価格もニューヨーク 先物価格との強い相関関係を持つ（図 2 、困 3 )。同じく拙稿で論じたように、競売価格と 先物価格が相関する理由は、上記の共謀（非 競争的取引)の結果、TCBが先物価格を考慮 して設定する最低価格が、ほほそのまま競売 価格となるからである(註15)。輸出価格と先 物価格が相関する理由は、以下で説明する輸 出業者と商社による価格設定の仕組みにあ る。

\section{2 ) 輸出価格形成の仕組み}

輸出価格（FOB）の設定方法は、基準の違 いにより、大きく2つに分類できる。1つ目 は、モシの競売価格を基準とするものであ り、キリマンジャロ原住民協同組合連合会 (KNCU) を初め、小規模業者、かつ競売価格 を尊重する（競売所で企業内取引を行ってい ない）業者による輸出の場合、この設定方法 が用いられる。すなわち、競売価格に倉庫経 費、港までの輸送経費、利益等を上乗せした 額を、輸出価格とする基本的な方法である。

しかし上記の平均価格で、逆ざやが生じ得 ることを考慮するだけでも、この川上側から コストを積み上げる基本的な競売基準方式 が、タンザニアでは支配的でないことを推測 できる。多国籍輸出業者が主導する支配的経
路の場合、ほとんどの業者が以下の川下側で 決まる価格に従属する設定方法を用いている のである。そしてコーヒー豆の輸出価格形成 に関しては、既に世界的にも、この $2 つ$ 目の 方法が支配的となっている。

それはニューヨークのコーヒー取引所で決 まる先物価格（世界のアラビカ豆の平均価 格）を基準とし、当該豆の品質や供給量、そ して輸出入業者間の力関係に沿った割増（プ レミアム)・割引（ディスカウント）を行い、 輸出価格（FOB）が設定される方法である。 ニューヨーク先物価格の最大の変動要因は、 世界のアラビカ豆貿易量（98年）の $30.8 \%$ を 占めるブラジル、 $21.1 \%$ 占めるコロンビア の供給量である。 $0.9 \% の$ 貿易シェアに甘んじ ているタンザニアの供給量の影響力は、皆無 であると言っても過言ではない（註 16）。

すなわち、タンザニア産マイルド・アラビ カ豆を日本に輸出する場合、ブラジル産豆と コロンビア産豆を「プライス・メーカー」と する、ニューヨーク先物価格（期近）が輸出 価格の基準となる。そして同豆は、コロンビ ア・マイルドに分類される最高品質豆である ため割増を上乗せし、さらに輸出時の同豆の 供給量、およびタンザニアの輸出業者と日本 の商社の力関係に沿った割増・割引を行い、 輸出価格が決まるのである（図 4)。

さらにその先物基準方式は、どの時点の先 物価格を基準にするかで、2つの設定方法に 分類できる。1つ目は契約成立時点の先物価 格を基準にする方法で、アウトライト（ジャ ン決め、フラット) 方式と呼ばれる。もう 1 つは、先物価格の変動を分析し、契約時に決 めた締め切り日（ファースト・ノウティス。 デイ）までに、自らにとって望ましいと判断 した日の価格で固定（フィックス）する方法 で、オープン（定期ベーシス）方式と呼ばれ る。売り手が固定権を持つセラーズ・コール と、買い手が固定権を持つバイヤーズ・コー ルがあるが、両者ともに価格変動リスクを負 
図 2 モシ競売所とニューヨーク取引所における取引価格の変化（US ドル $/ 50 \mathrm{~kg}$ ）

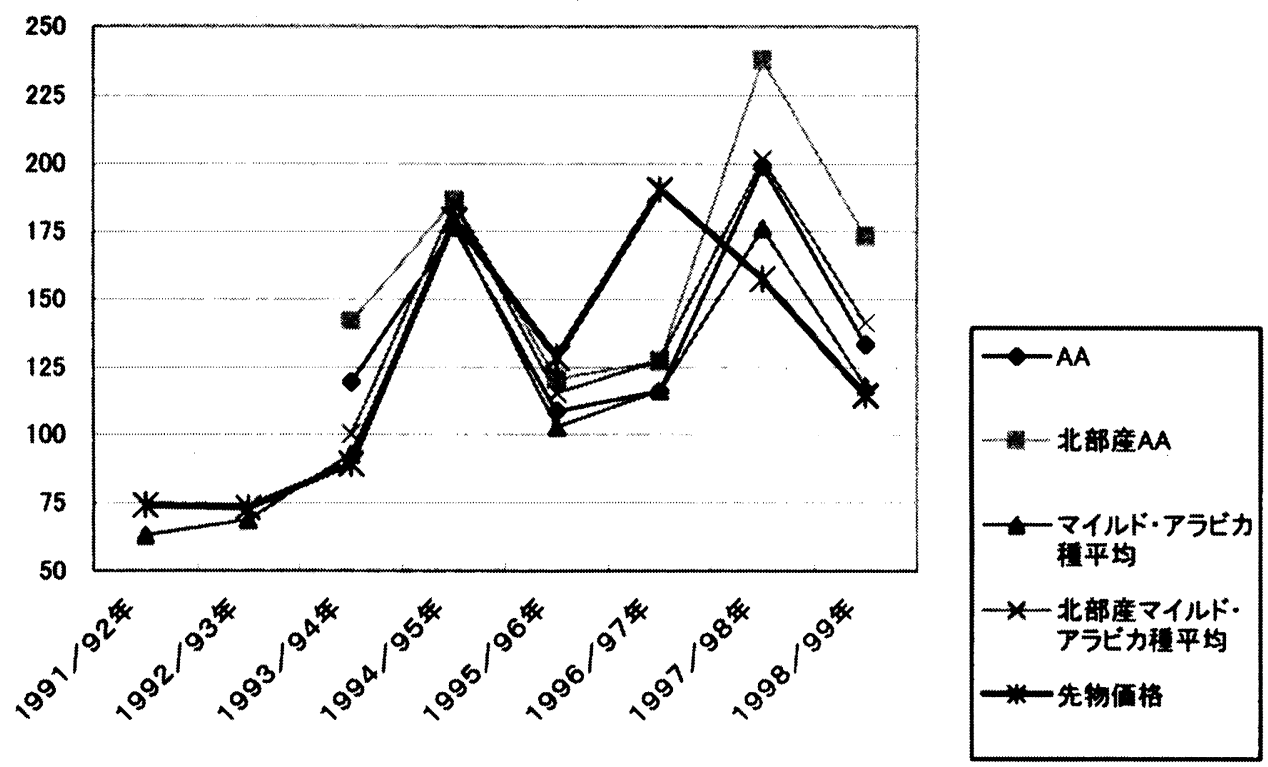

註：現物価格に関しては、Tanzania Coffee Board, Cummulative Action Sales, 先物価格（各年度の平均期 近価格）に関しては、「日本経済新聞』月曜版の「内外商品相場」、を参照して作成。

図 3 タンザニア産豆の日本への輸出価格とニューヨーク先物価格の变化（US ドル $/ 50 \mathrm{~kg} ）$

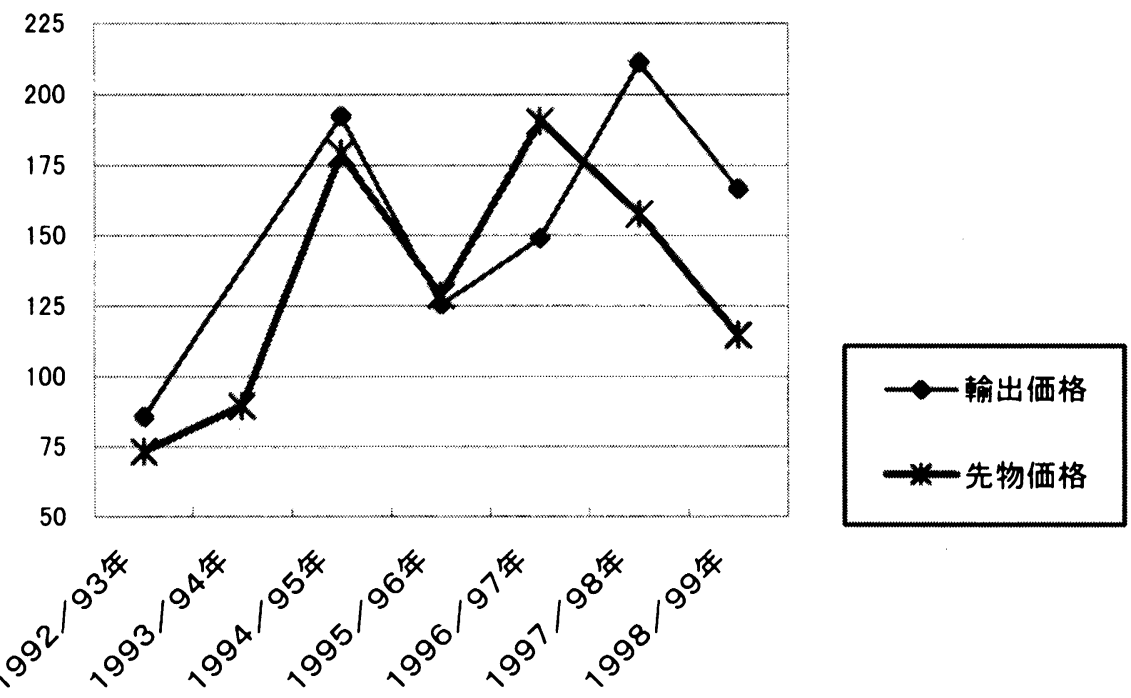

註：輸出価格（マイルド・アラビカ豆のFOB）に関しては、Tanzania Coffee Board, Cummulative Coffee Exports, 先物価格（各年度の平均期近価格）に関しては、『日本経済新聞』月曜版の 「内外商品相場」、を参照して作成。 
図 4 タンザニア産マイルド・アラビカ豆の輸出価格形成の概念図

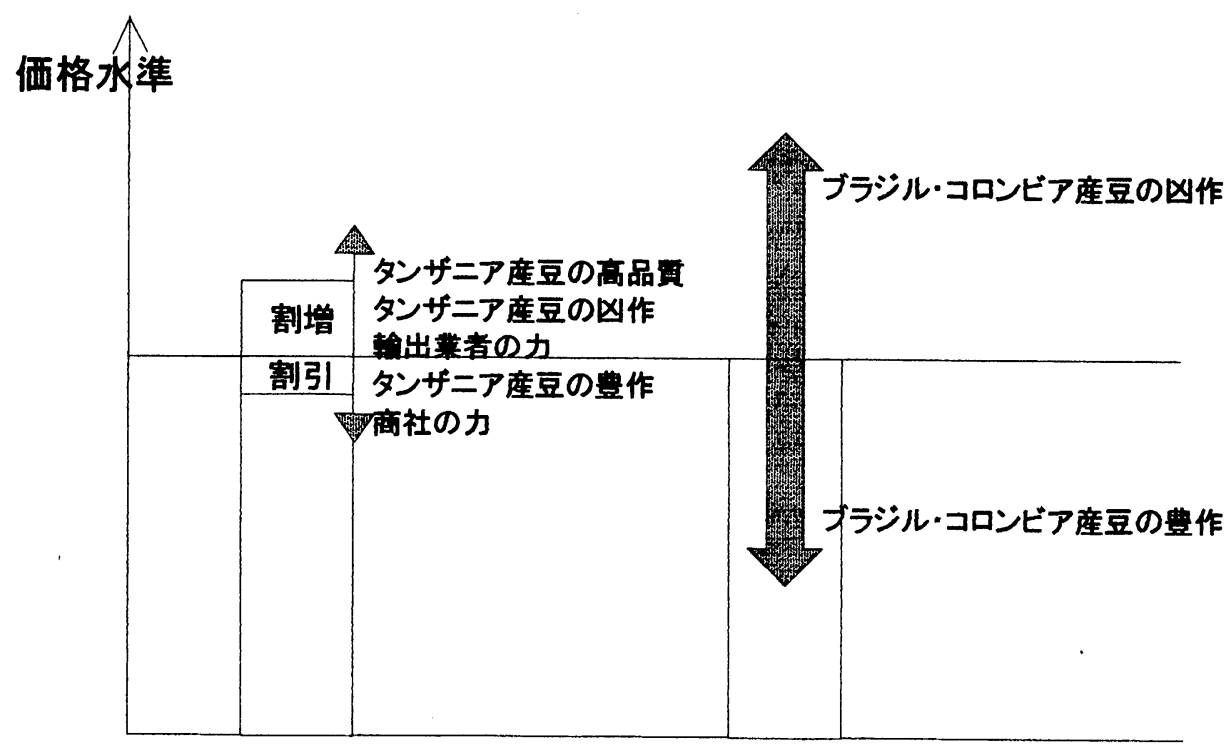

\section{タンザニア産豆翰出価格ニューヨーク先物価格}

うため、先物市場で保険つなぎ (ヘッジ)を 行うのが一般的である。オープン方式は、投 機利益を追求するための手法であり、西欧企 業、そして大規模業者になるほど、この投機 的リスクを抱えたがると言う。

日本企業の場合は、できる限り投機的リス クを避け、またできる限り早い価格固定を通 じた敏速な原価計算等を重視する傾向にあ る。しかし少なくともコーヒー豆の輸出価格 設定に関しては、たとえ日本企業であって も、現在では多くの業者が、2つ目のオープ ン方式を採用せざるを得なくなっている。特 に西欧系の輸出業者からの購入は、ほとんど が同方式に依っている。

イギリス系のACCからニチメンがタンザニ ア産マイルド・アラビカ豆を購入する場合 も、この事例に該当する。たたしACCは、二 チメンが求める稀少な高品質豆の販売に長け ているため、取引力が強い。その結果、彼ら のオープン方式は、最低価格が保障されたセ ラーズ・コールであり、ACCに有利なものと
なっている。すなわち成約時の先物価格（期 近）を最低価格とし、通常は船積み後 $3-5$ 日を締め切り日として先物価格を変動させ る。そして最も上昇したと判断した時点で先 物価格を固定し、それを基準に輸出価格が決 まるのである（価格が降下した場合は、成約 時の先物価格（最低価格）を基準)。

\section{3 ）割増・割引額の程度}

この先物価格を基準とする価格形成制度が ゆえに、タンザニア産マイルド・アラビカ豆 の輸出価格（FOB）は、ニューヨーク先物価 格に相関するのだと考えられる。また上記の ように、同豆の貿易シェアの過小さは、その 供給量の先物価格に対する影響力を皆無とし ている。ただし供給量によって変動する割 増・割引の程度が大きければ、輸出価格に対 する同豆の一定の影響力は確保されるであろ う。それゆえ本節では、割増・割引の程度を 明示する。

99 年度のタンザニアにおけるマイルド・ア 
ラビカ豆の生産量は、回復の兆しを見せては いるものの、未だ 96 年度からの異常気象にと もなう凶作から脱していない。また拙稿で説 いた同豆の品質の大幅なる低下は（拙稿 [14] pp.135-136)、日本が輸入する $\mathrm{AA}$ や $\mathrm{AB}$ の上質豆の供給量を大きく制限している。こ のプレミアム性を強く押し上げる供給条件の 下で、同豆のAA FAQやAB FAQに対する割 増額は、世界最高水準に至っている。

99 年末のニーヨーク先物価格が125から 135 セント/ポンドであった時期に、同豆(日 本向け）の割増額（業者間の力関係を考慮す る以前の見積額）は、AAFAQで+10から+ 16 セント/ポンドの水準、 $\mathrm{AB} \mathrm{FAQで+} 3$ か ら+6セント/ポンドの水準であったと言 う。なお、この割増・割引額は、国際的にも 業者間でも大きな違いはない。しかし日本に 対しては、例えば同じAAFAQであっても、 その中で最も上質な豆を求めるため、割増額 が多少、高めになると言う。

このように世界最高水準であるといって も、割増額は輸出価格の 1 割を占めるに過ぎ ない。この程度であれば、輸出価格に対する 同豆供給量の影響力は、些細なものであると 言わざるを得ないであろう。すなわちタンザ ニア産マイルド・アラビカ豆の輸出価格は、 ニューヨーク先物価格に従属しており、同豆 の供給量をほとんど反映しない。いわば同豆 の輸出価格は、ブラジル産豆とコロンビア産 豆の供給量で決まるのであり、タンザニア産 豆は「プライス・テーカー」の地位に甘んじ ているのである。

\section{5. 輸出価格形成制度の本質的問題と 対応方向一生産者価格引き上げ方 策の探求のために一}

2 節で明らかにしたように、最も上質で高 価なタンザニア産マイルド・アラビカ豆は、 ほとんどが日本へ輸出されている。全体の輸
出数量が停滞する中で、日本への高価豆の輸 出数量は増加傾向にある。日本が平均輸出価 格を引き上げる役割を果たしていることは、 タンザニアにおけるすべてのコーヒー産業の 関係者が認識している。

しかしながら 3 節で説いたように、日本の 業者は競売に参加できず、主に西欧系の民間 輸出業者からコーヒー豆を購入している。そ して 4 節で解明したように、西欧系の輸出業 者（同時に買付業者）にとって、非競争的で 所有権不移動の取引が支配的であるモシ競売 所における価格は、全く意味をもたず、輸出 価格設定の基準はニューヨーク先物価格であ る。その場合、拙稿で論じたように、生産者 価格は民間業者価格も協同組合価格も先物価 格に頭打ちされる(図 5 )。組合価格の上限は 競売価格であるが、共謀がゆえに競売価格と 先物価格が連動しているからである。先物価 格が上限である限り、たとえ構造調整政策で 買付競争を促し、民間業者間の競争が実現し たとしても、大きな価格上昇には至らないの である（註 17）。

ニューヨーク取引所における先物価格形成 制度の詳細な分析は、今後の課題となるが、 生産者の必要性を反映し難い、川下側に取引 所が立地していること、そしてそこで決まる 価格は、供給過多の状況下にある世界のアラ ビカ豆の平均価格であること、等を理由とし て、通常時であっても、ニューヨーク先物価 格は低迷を余儀なくされると考える。

さらに問題となるのは、ブラジル産豆ある いはコロンビア産豆の豊作を主因とする、先 物価格の急落時である。その場合、タンザニ ア産豆の輸出価格および生産者価格も落ち込 んでしまう。先物市場においては、投機家に よる取引が支配的であり、価格は容易に乱高 下する。ニューヨーク先物価格の急落は、日 本の業者による高めの購入など、全く意味を もたない程の暴落となる。そしてタンザニア 最大の輸出品の価格暴落は、同国の経済全体 
図 5 ニューヨーク先物価格とタンザニア産豆輸出価格・生産者価格の变化 (USドル $/ 50 \mathrm{~kg}$ )
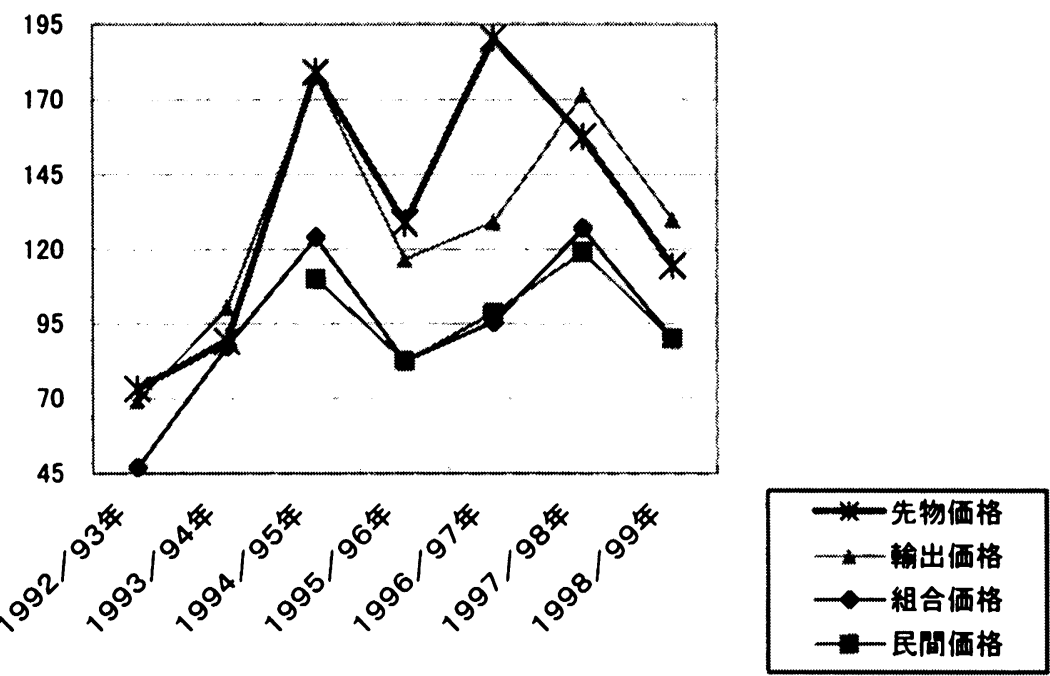

註：先物価格（各年度の平均期近価格）に関しては、「日本経済新聞」月曜版の「内外商品 相場」、輸出価格 (マイルド・アラビカ豆の FOB) に関しては、Tanzania Coffee Board, Cummulative Coffee Exports, 生産者価格（マイルド・アラビカ豆）に関しては、1994 年 度までは、Coffee Management Unit,Ministry of Agriculture,Coffee Production,Processing and Marketing 1976-1995 An Overview, 1996,p.26, 95 年度以降は、農村調査で得た一 次資料、を参照して作成。

に悪影響を及ほす。また生産者価格は、生産 費や生活費を無視して引き下がり、小農民の 生活をさらに困窮化させる。

その価格下落に、タンザニア産豆の需給量 はほとんど反映しない。少なくとも日本にお いて、タンザニア産豆の最高品質豆に限って は、「キリマンジャロ・コーヒー」として差別 化され、それを特別に嗜好する需要者が増加 している。またその最高品質豆の供給量は、 近年、大きく減少している。しかしこの価格 引き上げ要因となるべき需給関係が、輸出・ 生産者価格の暴落を妨げることはない。最も 深刻なのは、たとえば 98 年度のように、タン ザニア産豆全体の供給量と価格の同時なる低 迷、そして輸出の総額や生産者の売上の激減 が、容易に生じ得ることである（図 6 ）。

それらを避けるためには、ニューヨーク先 物価格の下落防止が不可欠となる。しかしな
がら、コーヒー豆輸出数量の統制によりその 防止を図った、国際コーヒー機構の輸出割当 制度は 89 年に崩壊した。その後の生産国カル テルの試み(93年のコーヒー生産国同盟の設 立）には、統制力と資金力の欠如がゆえに、 大きな成果を期待できない。

残された方策は、支配的経路とは別の新し い流通経路を創出し、ニューヨーク先物価格 に代わる有効な基準価格を備えた、新しい輸 出価格形成制度の確立をめざすことである。 そしてその基準価格は、「小国」の生産者の 必要性を反映できるものでなくてはならな w。

その試みの1つとして、消費国のNGOの主 導で発展しているオルタナティブ(フェア)・ トレード (AT) を挙げることができる。拙稿 で明示したように、日本におけるタンザニア 産コーヒー豆のATは、国際的なAT原則であ 
図 6 タンザニア産マイルド・アラビカ豆の生産者価格と生産量の関係

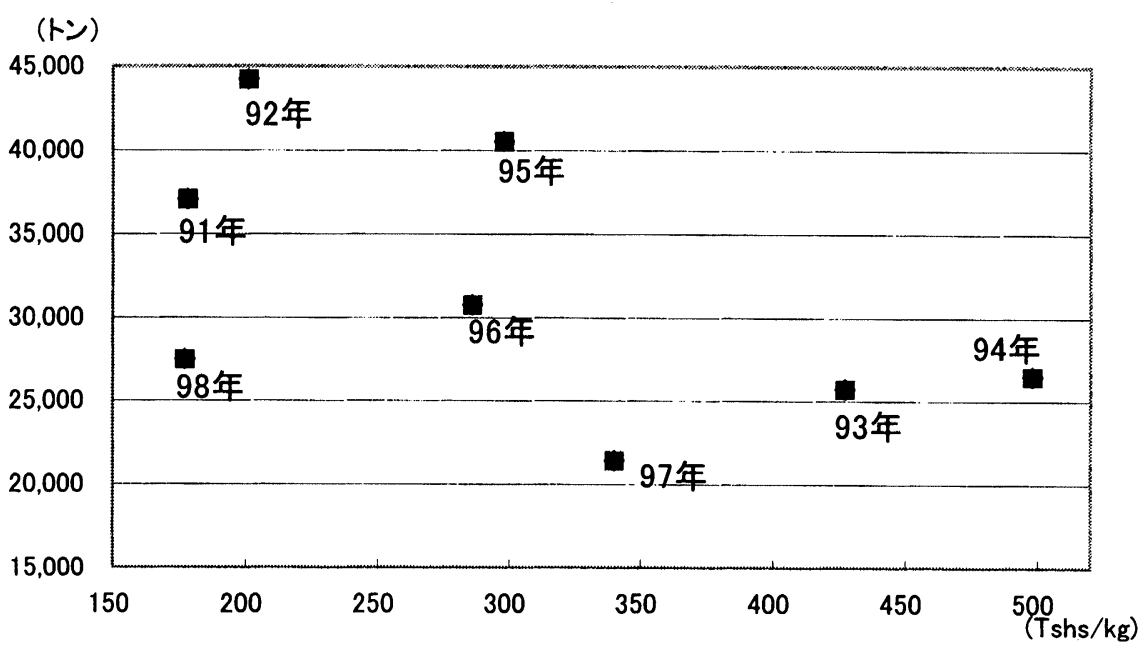

註：生産量に関しては、Tanzania Coffee Board, Coffee Production, 生産者価格（組合価格） に関しては、1994 年度までは、Coffee Management Unit,Ministry of Agriculture,Coffee Production,Processing and Marketing 1976-1995 An Overview,1996,p.26, 95 年度以降は、農 村調査で得た一次資料、を参照して作成。

る、1）最低輸出価格の固定（生産費を差し 引いても生産者に利益が残る最低水準の輸出 価格の保障)、2)生産地の社会開発等に利用 されるATプレミアムの支払、を満たすこと によって、生産者価格の下支え、引き上げに 努めると同時に、3）モシ競売所の現物価格 を基準とした輸出価格の設定、を行っている (註 18)。

3つ目の競売価格尊重が一般化され、同時 に競売所における購入競争が激化すれば（註 19)、同国産豆の供給量を競売価格、そして輸 出価格に反映させることができる。協同組合 や小農民組織による販売事業によって、生産 者価格を引き上げる可能性も生じる。そうな って初めて、タンザニア国内のコーヒー豆市 場において、価格メカニズムを機能させる環 境が整うのである。構造調整政策は、自由化 を推し進めることに懸命で、その環境整備の 視点に欠けていると言わざるを得ない。
（註 1 ）全日本コーヒー協会 [1］pp.89-90、 表(1)(2)（原典はICO-Statistics-onCoffee)、より算出。

（註 2 ）本論は、途上国の低開発の原因を、その 国が生産特化した一次産品の劣悪な交易条件 に求める「南北問題論」の流れを汲んでい る。それゆえフードシステム論で重視され ることの多い「流通の効率性」あるいは「消 費者にとっての公平性」よりも、筫しい「生 産者にとっての公平性小、特に生産者価格の 引き上げを重視する議論を行う。

（註 3 ) 同調査は、97年度文部省科学研究費補助 金（国際学術研究（研究代表者・池上甲 一))、99年度学術振興会科学研究費補助金 (奖励研究 $(\mathrm{A})) 、 99$ 年度文部省在外研究員 （若手教官）制度による助成を受けている。 ここに記して感謝の意を表したい。

（註 4 ） Bank of Tanzania［9］pp.24-25, を参照 して算出。

（註 5 ）Tanzania Coffee Board [10]，を参照し て算出。

(註 6 ) Bank of Tanzania, op. cit.

(註 7 ) Tanzania Coffee Board, op. cit.

（註 8 ）詳しくは、拙稿 [11］pp.43-44、を参照 
されたい。

(註 9 ) 98 年 2 月におけるACCコーヒー部長から の聞き取り。ただし通常はニチメンから購 入している生豆問屋の石光商事から、直接 的に注文が入ったり、イギリスの商社を通し て間接的にニチメンに販売することもある。 なおニチメンはその後、ACC 以外からの購 入も始めている。

（註10）東アフリカ最大の民間コーヒー流通業者 の 1 つで、ロンドンやスイスに本社を持つイ ギリス系の多国籍業者。

（註11）ACCコーヒー部長からの聞き取り。

（註12）輸出業者が船積前にサンプルを日本の業 者に送付し、日本の業者が味覚テストを初め とする品質検査を行う。そのサンプルを承認 すれば売買成立。

（註13）詳しくは、拙稿 [11］pp.33-36、を参照 されたい。

（註 14）詳しくは、同上稿、pp.43-44、を参照され たい。

（註 15）詳しくは、同上稿、pp.43-46、を参照され たい。

（註16）全日本コーヒー協会 [1]pp.36-39、 表 4（原典は大蔵省編『日本貿易月表』日本 関税協会)。

（註17）詳しくは、拙稿 [6]、を参照されたい。

（註 18）詳しくは、拙稿 [15]、を参照されたい。

（註 19）購入競争の激化のためには、拙稿 [6]

で論じたように、KNCUの買付シェアを回復 させ、組合 $(\mathrm{KNCU}) \rightarrow$ 民間の所有権移動取 引を強化する、およびそれが容易に移動しな いように、KNCU輸出部が競い合えるだけの 輸出シェアを確保することが必要であるが、 ATはKNCU輸出部からコーヒ豆を購入して いるため、その輸出力増強に貢献し得る。た だし現在のATのシェアは非常に小さいた め、競売価格尊重の一般化も輸出力増強への 貢献も、理想論に留まらざるを得ない。

\section{引用文献}

[1]全日本コーヒー協会『コーヒー関係統 計』、1999年 10 月。

[2] Mahalu, C. R., International Primary Control Schemes in World Trade with Particu- lar Reference to the I. C. A. and Tanzania, Master Thesis, University of Dar es Salaam, 1976.

[ 3 ] Musuya, Michael M., Coffee in the Economy of Tanzania and the Implications of Membership in the International Coffee Agreement, Ph. D. Thesis, University of Wisconsin, 1979.

[4] Chenza, Charles M., The Impact of Economic Reform Programmes on Coffee Growers' Incomes in Tanzania, Master Thesis, University of Dar es Salaam,1998.

[5] Temu, Anna. A., Empirical Evidence of Changes in the Coffee Market after Liberalization: A Case of Northern Tanzania, Ph. D. Thesis, University of Illinois, 1999.

[6] 辻村英之「タンザニアにおけるコーヒー豆 の流通構造一新しい価格形成制度の現状と課 題一」『月刊 アフリカ』1999年12月号、 pp.4-8、及び 2000 年 1 月号、pp.15-18。

[ 7 ] Mwaikambo, W. S., Coffee Marketing Review 1993/94, Marketing Development Bureau, Ministry of Agriculture in Tanzania, 1995.

[ 8] Daily News, August 8, 1993.

[9] Bank of Tanzania, Report of the Committee of Bank of Tanzania on the Performance of the Coffee Authority of Tanzania, 1988.

[10] Tanzania Coffee Board, Cummulative Coffee Exports, 1992/93-1998/99.

[11］辻村英之「タンザニアにおけるコーヒー豆 流通自由化の実態と小農民·協同組合への影 響一流通・格付・価格形成制度の変容を中心 に一」『コーヒー文化研究』第 6 号、1999年 12 月、pp. $30-50$ 。

[12] Tanzania Coffee Board, Auction Sale No. TCB/M13 \& H14 Held on 26.2.98.

[13] Tanzania Coffee Board, Actual Coffee Exports for the Month of March,1998.

[14] 辻村英之「タンザニアにおけるコーヒー産 業の構造調整と品質管理問題」『金沢大学経 済学部論集』第 20 巻第 1 号、 2000 年 3 月、 pp.133-155。

[15] 辻村英之「タンザニア産コーヒー豆のオル タナティブな流通経路・価格形成制度の探究 


$$
\text { タンザニア産コーヒー豆の輸出構造と価格形成制度 }
$$

一日本におけるオルタナティブ・トレードの 実践一」『金沢大学経済学部論集』第 21 巻第

1 号、 2001 年 1 月、pp.177-196。
著者アドレス：

干 920-1192 金沢市角間町 金沢大学経済学部 